\title{
Interactions between the extracellular domain and the extracellular loops as well as the 6th transmembrane domain are necessary for TSH receptor activation
}

\author{
Susanne Neumann, Maren Claus and Ralf Paschke \\ III Medical Department, University of Leipzig, Philipp-Rosenthal-Str. 27, 04103 Leipzig, Germany
}

(Correspondence should be addressed to R Paschke; Email: pasr@medizin.uni-leipzig.de)

\begin{abstract}
Objective: The molecular mechanisms of TSH receptor (TSHR) activation and intramolecular signal transduction are largely unknown. Deletion of the extracellular domain (ECD) of the TSHR results in increased constitutive activity, which suggests a self-inhibitory interaction between the ECD and the extracellular loops (ECLs) or the transmembrane domains (TMDs). To investigate these potential interactions and to pursue the idea that mutations in the ECD affect the constitutive activity of mutants in the ECLs or TMDs we generated double mutants between position 281 in the ECD and mutants in all three ECLs as well as the 6th TMD.

Design: We combined mutation S281D, characterized by an impaired TSH-stimulated cAMP response, with the constitutively activating in vivo mutations I486F (1st ECL), I568T (2nd ECL), V656F (3rd ECL) and D633F (6th TMD). Further, we constructed double mutants containing the constitutively activating mutation S281N and one of the inactivating mutations D474E, T477I (1st ECL) and D633K (6th TMD).

Results: The cAMP level of the double mutants with S281N and the inactive mutants in the 1st ECL was decreased below the level of the inactive single mutants, demonstrating that a constitutively activating mutation in the ECD cannot bypass disruption of signal transduction in the serpentine domain. In double mutants with S281D, basal and TSH-induced cAMP and inositol phosphate production of constitutively active mutants was reduced to the level of S281D.

Conclusion: The dominance of S281D and the dependence of constitutively activating mutations in the ECLs on the functionally intact ECD strongly suggest that interactions between these receptor domains are required for TSHR activation and intramolecular signal transduction.
\end{abstract}

European Journal of Endocrinology 152 625-634

\section{Introduction}

The thyrotropin (TSH) receptor (TSHR) together with the luteinizing hormone receptor (LHR) and the follicle-stimulating receptor (FSHR) is a member of the seven transmembrane-spanning receptors (7TMRs) $(1,2)$ and belongs to the subfamily of glycoprotein hormone receptors (GPHR) $(3,4)$. GPHRs are unique among 7TMRs because of their extraordinarily long extracellular ligand-binding domain (350 amino acids) $(5,6)$ consisting of leucine-rich repeats (LRR) $(7-13)$. This receptor domain is known for its high-affinity hormone binding $(14,15)$. It is assumed that hormone binding induces a more open conformation of the receptor, in which the ectodomain is released from the helical bundles $(16,17)$. After hormone binding, the signal is predicted to pass on to the extracellular loops (ECLs), transmembrane domains (TMDs) and intracellular loops (ICLs) of the TSHR to induce an activated conformation of the receptor, which allows activation of $\mathrm{G}$ proteins. Therefore, interactions between these receptor domains are very likely involved in intramolecular signal transduction.

In contrast to the LHR and FSHR, the wild-type (wt) TSHR shows basal cAMP activity in the absence of the ligand (18). Proteolytic degradation (19), deletions in the ectodomain region 339-367 (20) or the deletion of the entire extracellular domain (ECD) (17) also lead to constitutive TSHR activation. Zhang et al. (17) postulated that the functionally intact ectodomain plays a key role in stabilizing the inactive conformation of the TSHR as an internal antagonist. Electrostatic selfinhibitory interactions between the ECD and the ECLs have been suggested.

A TSHR construct containing a truncated ECD can be fully activated by the activating mutants D633A in the 6th TMD and A623I in the 3rd ICL (16). In contrast, the constitutively activating mutants $\mathrm{I} 486 \mathrm{~F}$ 
and I568T in the 1st and 2nd ECLs or the deletion del658-661 lose constitutive activity after deletion of the ECD (16). These findings support a model in which activation of the cAMP pathway of the TSHR involves switching of the ectodomain from a tethered inverse agonist to an agonist $(16,17)$. Moreover, this suggests that full stimulation of cAMP production by the TSHR involves more than the release of the ectodomain silencing effect on the serpentine domain. In fact, the ectodomain is proposed to have a positive effect on the activity of the serpentine domain $(16,17)$.

Naturally occurring TSHR mutations, which have been identified as one of the molecular causes of hyperfunctioning thyroid adenomas, are mainly localized in the transmembrane domains as well as in the ECLs and ICLs (TSH Receptor mutation Database II, http:// www.uni-leipzig.de/ innere/) $(21,22)$. These in vivo mutations give valuable indications for specific functional features, which are important for the analysis of intra- and intermolecular structure-function relationships. S281 is the only position in the extracellular domain which is affected by constitutively activating in vivo TSHR mutations (S281T, I and N) (2326). The receptor region around S281 is highly conserved among the glycoprotein hormone receptors (24). In a recent study, we replaced S281 by all other 19 amino acids. Constitutive TSHR activation was observed by 15 amino acid substitutions (H Jaeschke, S Neumann, G Kleinau, M Claus, G Krause and R Paschke, unpublished observations). In contrast, the charged residues $\mathrm{K}, \mathrm{R}$ and $\mathrm{D}$ were hardly expressed on the cell surface resulting in loss of or a strong impairment of TSH binding. As a consequence, Gsand Gq-protein coupling was completely abolished in the case of S281K and S281R. Surprisingly, S281D led to constitutive activation of the TSHR; however, further response to TSH was strongly reduced in this mutant (H Jaeschke, S Neumann, G Kleinau, M Claus, G Krause and R Paschke, unpuplished observations). This decreased responsiveness to TSH stimulation by S281D is most probably caused by conformational changes, which prevent efficient receptor expression and function on the cell surface. Mutagenesis of the LHR at the corresponding position 277 has also shown that except for $\mathrm{R}, \mathrm{K}$ and $\mathrm{D}$ all other amino acid substitutions lead to constitutive activity at varying levels (27). S281 seems to play a pivotal role for the intramolecular signal transduction of the TSHR and, moreover, the vicinity of S281 is suggested to stabilize the structure of the ECD (24).

In order to investigate in more detail the structural influence of S281 on TSHR activation and signal transduction and to investigate potential interactions between the ECD and the ECLs and the 6th TMD as well as interdependence between these domains, we constructed double mutants between position S281 in the ECD and mutations in the ECLs and the 6th

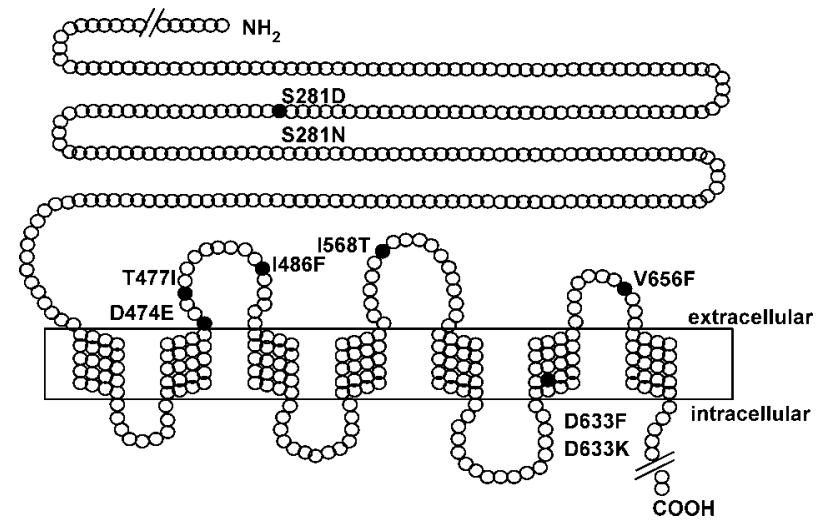

Figure 1 Localization of TSHR mutations. Schematic representation of the TSHR with indications of mutated residues. Residue numbers are determined by counting from the methionine start site of the TSHR.

TMD (Fig. 1) guided by naturally occurring TSHR mutations.

\section{Materials and methods}

\section{Site-directed mutagenesis}

The TSHR double mutants were constructed by standard PCR mutagenesis techniques (28) using the human TSHR plasmid TSHR-pSVL as template (29). Except for the mutants S281D/I486F, S281N/D474E and S281N/T477I, the PCR fragments were digested with Eco81I and Eco91I (MBI Fermentas, Vilnius, Lithuania). For the S281D/I486F double mutant, the PCR fragment was incompletely digested with ScaI (MBI Fermentas), because of an additional Scal site within the pSVL vector, and subsequently digested with Eco91I. The double mutant S281N/D474E was generated by digestion of the PCR fragment with AflII and Eco81I (MBI Fermentas). The PCR fragment with the mutation T477I was digested with AflI and Eco91I. The fragments obtained were used to replace the corresponding fragments in the TSHR-pSVL constructs containing the S281D and S281N mutations respectively. Mutated TSHR sequences were verified by dideoxy sequencing with dRhodamine Terminator Cycle Sequencing chemistry (ABI Advanced Biotechnologies, Inc., Columbia, MD, USA). Sequencing reactions were analyzed on a Genetic analyzer ABI 310 (Applied Biosystems, Darmstadt, Germany).

\section{Cell culture and transient expression of mutant TSHRs}

COS-7 cells were grown in Dulbecco's modified Eagle's medium (DMEM) supplemented with 10\% fetal calf serum, $100 \mathrm{U} / \mathrm{ml}$ penicillin and $100 \mu \mathrm{g} / \mathrm{ml}$ streptomycin (Gibco Life Technologies, Paisley, Strathclyde, UK) at $37^{\circ} \mathrm{C}$ in a humified $5 \% \mathrm{CO}_{2}$ incubator. Cells were 
transiently transfected in 12 -well plates $\left(1 \times 10^{5}\right.$ cells per well) or 24 -well plates $\left(0.5 \times 10^{5}\right.$ cells per well) with $1 \mu \mathrm{g}$ or $0.5 \mu \mathrm{g}$ DNA per well respectively, using the FuGene 6 reagent (Roche, Basel, Switzerland).

\section{FACS analyses}

Transfected cells were detached from the dishes with 1 mM EDTA and $1 \mathrm{mM}$ EGTA in phosphate-buffered saline (PBS) and transferred in Falcon 2052 tubes. Cells were washed once with PBS containing 0.1\% bovine serum albumin (BSA) and $0.1 \% \mathrm{NaN}_{3}$ and then incubated at $4^{\circ} \mathrm{C}$ for $1 \mathrm{~h}$ with a $1: 200$ dilution of a mouse anti-human TSHR antibody (2C11; $10 \mathrm{mg} / \mathrm{l}$; Serotec Ltd, Oxford, Oxon, UK) in the same buffer. For permeabilized cell assays, cells were first fixed with $1 \%$ paraformaldehyde for $10 \mathrm{~min}$ on ice followed by permeabilization with PBS containing 0.1\% BSA, $0.1 \% \mathrm{NaN}_{3}$ and $0.2 \%$ saponin for $30 \mathrm{~min}$. Thereafter, cells were incubated with the primary antibody in the same buffer at $4{ }^{\circ} \mathrm{C}$ for $1 \mathrm{~h}$. All subsequent buffers were supplemented with saponin. Tubes were washed twice and incubated at $4^{\circ} \mathrm{C}$ for $1 \mathrm{~h}$ with a 1:200 dilution of fluorescein-conjugated $\mathrm{F}\left(\mathrm{ab}^{\prime}\right) 2$ rabbit anti-mouse IgG (Serotec). Before FACS analysis (FACScan; Becton Dickinson and Co., Franklin Lakes, NJ, USA) cells were washed twice and then fixed with $1 \%$ paraformaldehyde. Receptor expression was determined by the fluorescence intensity, whereas the percentage of signal-positive cells corresponds to the transfection efficiency.

\section{CAMP accumulation assay}

Forty eight hours after transfection, determination of cAMP accumulation was performed as previously described (30).

\section{Stimulation of inositol phosphate (IP) formation}

Forty hours after transfection, cells were incubated with $2 \mu \mathrm{Ci} / \mathrm{ml}\left[\mathrm{myo}^{3} \mathrm{H}\right]$ inositol $(18.6 \mathrm{Ci} / \mathrm{mmol}$; Amersham Pharmacia Biotech, Braunschweig, Germany) for $8 \mathrm{~h}$. Thereafter, cells were preincubated with serum-free DMEM without antibiotics containing $10 \mathrm{mM} \mathrm{LiCl}$ for $30 \mathrm{~min}$. Stimulation by TSH was performed in the same medium containing $100 \mathrm{mU} / \mathrm{ml}$ bovine (b) TSH (Sigma Chemical Co.) for $1 \mathrm{~h}$. Intracellular IP levels were determined by anion exchange chromatography as described (31). IP values are expressed as the percentage of radioactivity incorporated from $\left[{ }^{3} \mathrm{H}\right]$ inositol phosphates (IP1-3) over the sum of radioactivity incorporated in IPs and phosphatidyl inositoles (PI).

\section{Radioligand binding assay}

Competitive binding studies were performed as previously described (32). $\left[{ }^{125} \mathrm{I}\right] \mathrm{bTSH}$ was obtained from BRAHMS Diagnostica, Hennigsdorf, Germany. Data were analyzed assuming a one-site binding model using GraphPad Prism 2.01 for Windows (33).

\section{Results}

The functional characteristics of mutant TSHRs were studied by transient expression in COS-7 cells. Cells transfected with a DNA construct encoding the wt TSHR or the empty pSVL vector were used as controls. Except for S281D, all constitutively activating or inactivating single TSHR mutations have already been functionally characterized $(23,32,34-39)$. The effects of all mutations on TSH binding, cell surface expression, basal and TSH-stimulated cAMP and IP accumulation are summarized in Table 1.

\section{Double mutants with S281D and constitutively activating mutations in all ECLs and the 6th TMD}

In order to characterize the effect of a mutation with a reduced responsiveness to TSH in the ECD on constitutively active mutants in the serpentine domain, we constructed double mutants with S281D and the constitutively activating mutations $\mathrm{I} 486 \mathrm{~F}$ in the 1 st ECL, I568T in the 2nd ECL, V656F in the 3rd ECL and D633F located in the 6th TMD respectively (Fig. 1).

The S281D mutant was characterized by a low cell surface expression (Table 1 and Fig. 2A and C). To exclude strongly diminished receptor synthesis, FACS analysis was performed on permeabilized cells. The S281D mutant was clearly detectable within the cells (Fig. 2A and C) indicating that mutated receptors were expressed; however, folding and/or trafficking were affected. Cells transfected with S281D construct showed constitutive cAMP production, but further cAMP formation after stimulation with TSH was markedly reduced (Table 1 and Fig. 3A). No IP production was detected in the absence or presence of TSH, which is most likely associated with the diminished cell surface expression and response to TSH (Fig. 4B).

All double mutants with S281D showed a significant decrease in cell surface expression and reached only the expression level of D281 (Table 1 and Fig. 2). However, these mutants showed also an intracellular receptor accumulation as observed with S281D (Fig. 2). Cells transfected with these constructs were still constitutively active with regard to cAMP production; however, their basal activity was reduced to the level of S281D or even lower (Table 1 and Fig. 3A). The stimulated cAMP production of all constitutively activating single mutants in the 1st, 2nd and 3rd ECLs was decreased 
Table 1 Functional characterization of TSHR single and double mutants. COS-7 cells were transfected with the wt TSHR or the described mutant TSHRs. Functional assays were carried out as described in Materials and methods. Because of the basal activity of the wt TSHR, cAMP levels are expressed as relative to wt TSHR basal (set at 1). Maximum increase in cAMP and IP levels were determined after stimulation with $100 \mathrm{mU} \mathrm{bTSH} / \mathrm{ml}$. $B_{\max }$ values were determined by homologous competitive binding experiments. The TSHR cell surface expression was quantified on a FACS flow cytometer. Data are given as means \pm S.E.M. of two independent experiments, each carried out in triplicate. The PSVL vector was used as a control.

\begin{tabular}{|c|c|c|c|c|c|c|}
\hline \multirow[b]{2}{*}{$\begin{array}{l}\text { Transfected } \\
\text { construct }\end{array}$} & \multirow{2}{*}{$\begin{array}{c}{\left[{ }^{125} \mathrm{I}\right]-\mathbf{b T S H} \text { binding }} \\
B_{\max } \\
(\% \text { of wt TSHR) }\end{array}$} & \multirow{2}{*}{$\begin{array}{c}\text { Cell surface expression } \\
\text { FACS } \\
\text { (\% of wt TSHR) }\end{array}$} & \multicolumn{2}{|c|}{ cAMP accumulation } & \multicolumn{2}{|c|}{ IP accumulation } \\
\hline & & & \multicolumn{2}{|c|}{$\begin{array}{l}\text { Basal Stimulated } \\
\text { (Relative to wt basal) }\end{array}$} & \multicolumn{2}{|c|}{$\begin{array}{l}\text { Basal Stimulated } \\
\quad(I P s(\%(I P s+P I)))\end{array}$} \\
\hline TSHR wt & 100 & 100 & 1 & $14.6 \pm 1.1$ & $2.9 \pm 0.5$ & $32.8 \pm 3.9$ \\
\hline S281D & $13.3 \pm 0.5$ & $16.7 \pm 1.4$ & $5.3 \pm 0.3$ & $8.6 \pm 0.3$ & $2.0 \pm 0.05$ & $2.3 \pm 0.4$ \\
\hline $1486 \mathrm{~F}$ & $41.5 \pm 3.1$ & $35.0 \pm 2.2$ & $8.2 \pm 0.7$ & $12.1 \pm 1.3$ & $2.8 \pm 0.6$ & $17.8 \pm 0.1$ \\
\hline S281D/I486F & $8.1 \pm 0.4$ & $16.2 \pm 0.4$ & $4.8 \pm 0.5$ & $7.0 \pm 0.1$ & $1.9 \pm 0.3$ & $2.5 \pm 0.9$ \\
\hline $1568 \mathrm{~T}$ & $67.2 \pm 3.6$ & $64.8 \pm 2.4$ & $5.2 \pm 0.0$ & $13.5 \pm 0.4$ & $2.2 \pm 0.3$ & $27.1 \pm 4.2$ \\
\hline S281D//568T & $5.3 \pm 0.3$ & $15.9 \pm 3.5$ & $5.6 \pm 0.02$ & $6.9 \pm 0.6$ & $1.9 \pm 0.1$ & $1.9 \pm 0.3$ \\
\hline D633F & $45.3 \pm 1.1$ & $39.7 \pm 2.5$ & $6.1 \pm 0.4$ & $16.0 \pm 0.5$ & $3.7 \pm 0.2$ & $16.3 \pm 1.8$ \\
\hline S281D/D633F & $8.8 \pm 0.3$ & $22.6 \pm 0.6$ & $5.3 \pm 0.8$ & $7.3 \pm 0.3$ & $2.2 \pm 0.2$ & $2.8 \pm 0.9$ \\
\hline V656F & $97.9 \pm 0.0$ & $88.6 \pm 3.8$ & $7.1 \pm 0.4$ & $11.3 \pm 0.7$ & $2.3 \pm 0.5$ & $16.2 \pm 0.4$ \\
\hline S281D/V656F & $13.2 \pm 1.0$ & $23.3 \pm 0.3$ & $5.3 \pm 0.3$ & $5.5 \pm 0.4$ & $2.9 \pm 0.9$ & $3.0 \pm 0.2$ \\
\hline S281N & $66.8 \pm 2.3$ & $60.6 \pm 0.9$ & $5.3 \pm 0.8$ & $14.4 \pm 0.2$ & $1.9 \pm 0.3$ & $18.3 \pm 2.5$ \\
\hline D474E & $44.2 \pm 1.9$ & $36.5 \pm 5.7$ & $0.5 \pm 0.02$ & $4.3 \pm 0.04$ & $2.9 \pm 0.1$ & $2.7 \pm 0.5$ \\
\hline S281N/D474E & $4.5 \pm 0.5$ & $14.9 \pm 0.1$ & $0.2 \pm 0.02$ & $1.4 \pm 0.01$ & $1.7 \pm 0.2$ & $2.0 \pm 0.05$ \\
\hline T477I & $27.2 \pm 0.2$ & $24.4 \pm 1.4$ & $0.6 \pm 0.02$ & $4.1 \pm 0.1$ & $2.2 \pm 0.05$ & $2.3 \pm 0.3$ \\
\hline S281N/T477I & $2.9 \pm 0.2$ & $10.5 \pm 0.4$ & $0.3 \pm 0.02$ & $1.3 \pm 0.1$ & $1.8 \pm 0.1$ & $2.5 \pm 0.05$ \\
\hline D633K & $59.8 \pm 0.1$ & $82.2 \pm 0.8$ & $1.5 \pm 0.3$ & $5.0 \pm 0.6$ & $2.1 \pm 0.02$ & $2.9 \pm 0.8$ \\
\hline S281N/D633K & $27.6 \pm 1.1$ & $44.5 \pm 1.1$ & $0.4 \pm 0.1$ & $1.4 \pm 0.03$ & $2.1 \pm 0.3$ & $2.8 \pm 0.5$ \\
\hline pSVL & & & $0.2 \pm 0.03$ & $1.2 \pm 0.2$ & $3.0 \pm 0.3$ & $3.5 \pm 0.7$ \\
\hline
\end{tabular}

to or below the level of TSH-induced cAMP accumulation of S281D in the double mutants. While constitutively active single mutants I486F, I568T, V656F and D633F showed a clear increase in IP accumulation after stimulation with TSH, cells expressing the double mutants with S281D did not show IP production in the absence or presence of TSH (Table 1 and Fig. 4A). Thus all double mutants with S281D displayed the phenotype of the S281D single mutant.

\section{Double mutants with $S 281 N$ and inactivating mutants in the 1st ECL and the 6th TMD}

In an opposite approach, the effects of a constitutively activating mutation with a TSH-induced cAMP response comparable with the wt TSHR at position 281 on inactive mutants in the 1st ECL and the 6th TMD respectively were tested. We combined the constitutively activating mutation S281N in the ECD with one of the inactive mutants D474E and T477I in the 1st ECL or D633K in the 6th TMD (Fig. 1).

No rescue of TSHR activation could be achieved by the double mutants S281N/D474E and S281N/T477I. In fact, cells transfected with these constructs were completely inactive for cAMP production (Table 1 and Fig. 3B). Both double mutants showed a reduced cell surface expression compared with the corresponding single mutants (Table 1). However, the mutated receptors were detectable within the cells measured by FACS analysis on permeabilized cells (Fig. 2B and D). This finding suggests that these receptors are expressed; however, these double mutations interfere with accurate folding and trafficking of the receptor to the plasma membrane (Fig. 2).

For the S281N/D633K mutant, cAMP production was decreased to about $30 \%$ of the level of the D633K single mutant, even though the D633K single mutant showed a slight increase of cAMP accumulation after stimulation with TSH (Table 1 and Fig. 3B). In addition, no IP accumulation was detectable in all double mutants (Table 1 and Fig. 4B), underlining the complete inability of these mutants to activate Gs- and Gq-mediated signaling.

\section{Discussion}

Recent studies have proposed several activation models for glycoprotein hormone receptors with regard to the interaction between the ectodomain and the ECL/TMD region. The extracellular domain of the TSHR has been suggested to act as an internal antagonist (17) or to function as a molecular switch, displaying agonist or inverse agonist properties, depending on whether it is bound to its ligand or not (16). Deletion of the ectodomain of the LHR does not lead to constitutive receptor activation as has been shown for the TSHR. For the LHR, the intact leucine-rich repeat-containing domain is essential for constitutive activation by mutations in the hinge region, which is situated between the LRR motif and the seven transmembrane-spanning domain. This finding suggests that the ectodomain of the LHR functions as an intramolecular agonistic 
non-permeabilized

permeabilized

wt TSHR
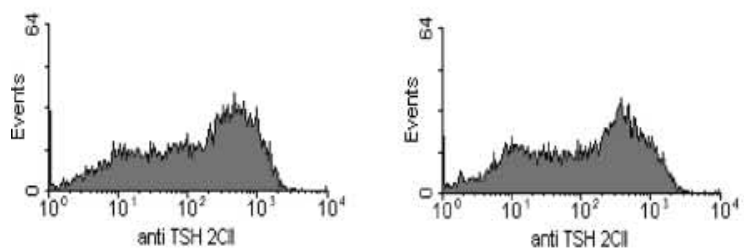

A Double mutants with S281D

S281D
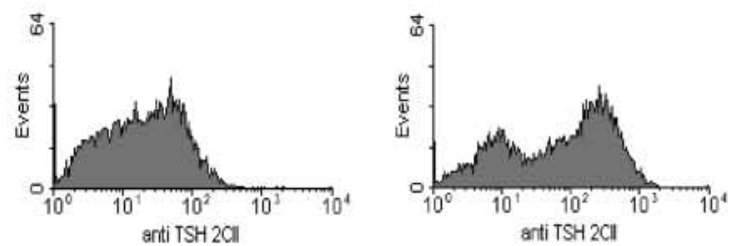

I568T

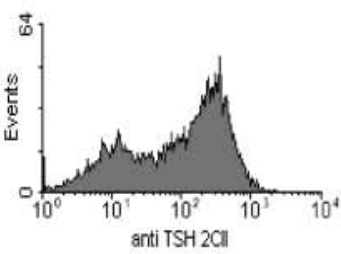

S281D/I568T

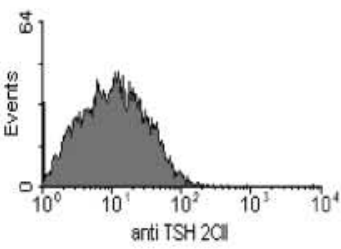

D633F

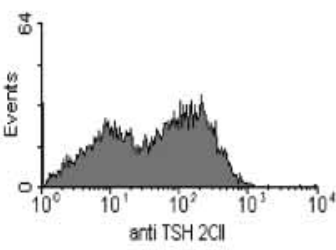

S281D/D633F

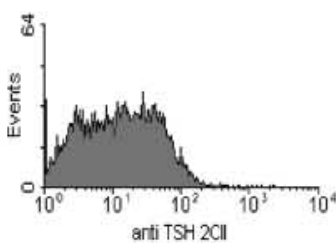

Figure 2 Continued. non-permeabilized

permeabilized

pSVL
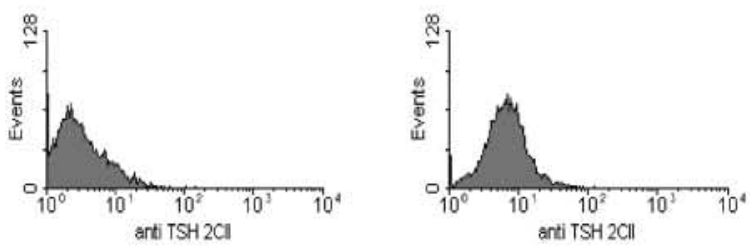

B Double mutants with S281N

$\mathrm{S} 281 \mathrm{~N}$
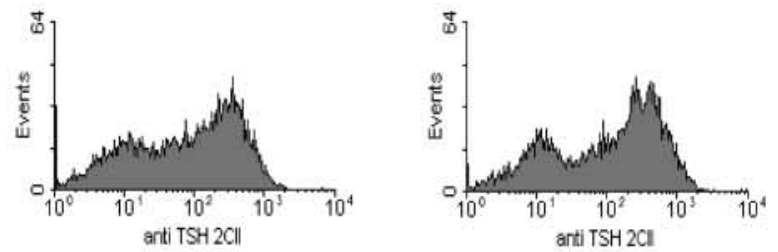

D474E
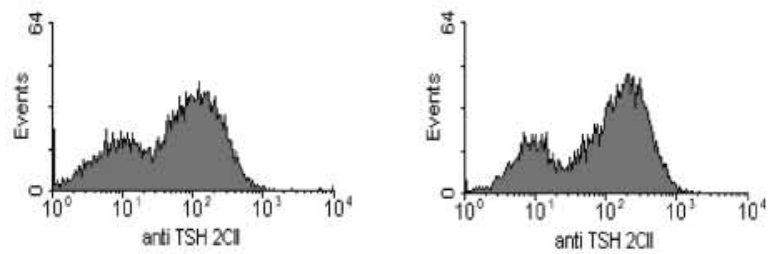

S281N/D474E
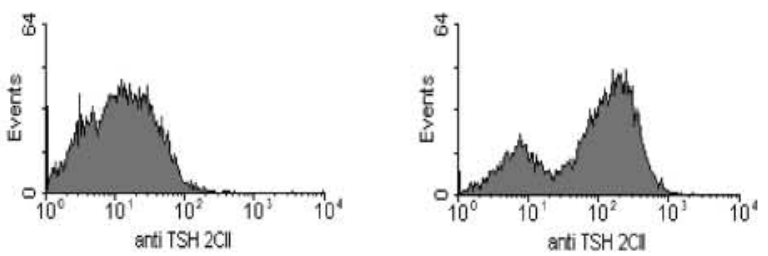

D633K
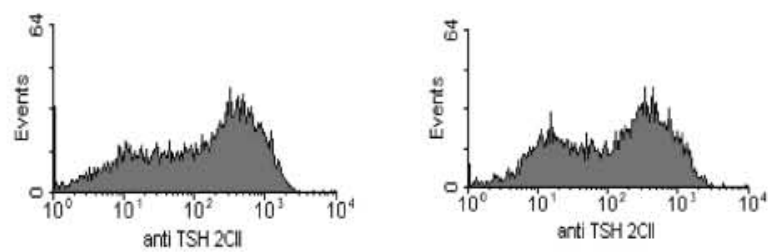

\section{S281N/D633K}
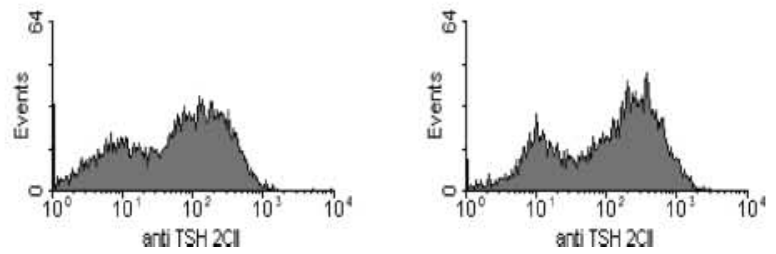

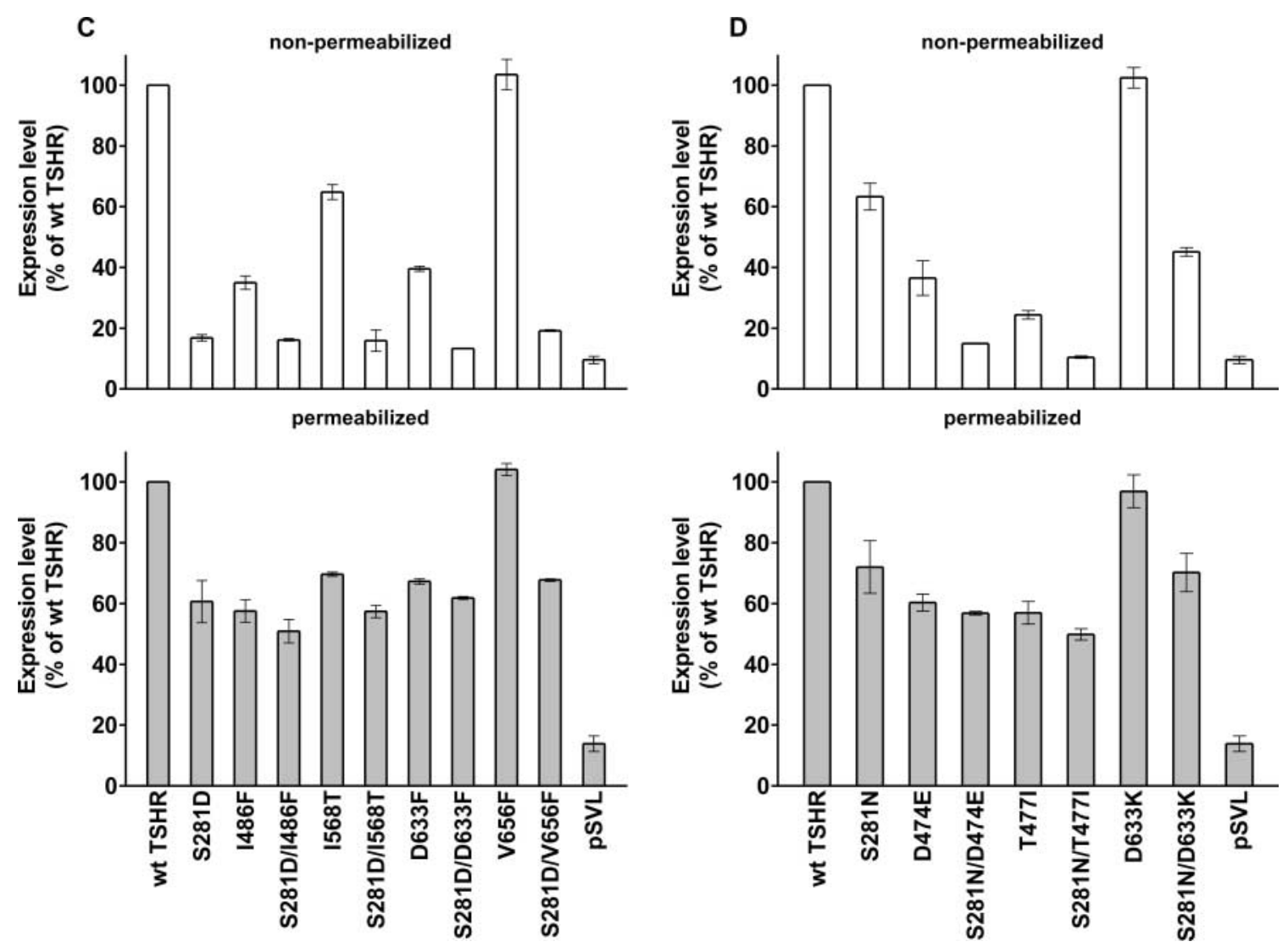

Figure 2 Cell surface expression determined by (A) flow immunocytometry. (B) Non-permeabilized cells and saponin-permeabilized cells were assayed after transfection with pSVL-vector (as control), wt TSHR and mutants. Fluorescence intensity is expressed in arbitrary units as a function of cell number plotted on a logarithmic scale. Representative mutants are shown. (C) Expression level of all double mutants with S281D and (D) expression level of all double mutants with S281N and the corresponding single mutants. FACS analyses were performed on intact (upper graphs) and permeabilized (lower graphs) COS-7 cells transfected identically. Data are expressed as percentage expression of wt TSHR (set at 100\%) and are presented as means \pm S.E.M. of two independent experiments, each carried out in duplicate.
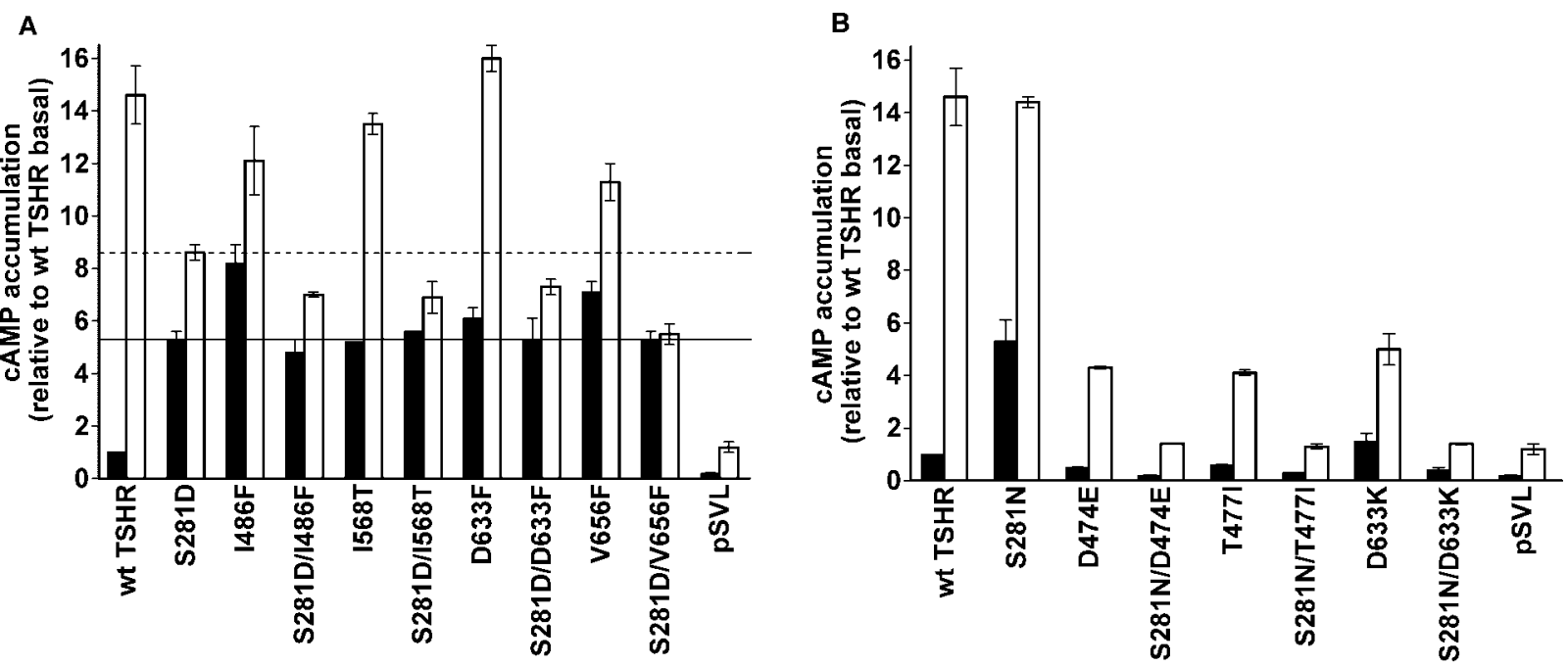

Figure 3 Basal and TSH-stimulated cAMP accumulation. (A) wt and TSHR double mutants with S281D and corresponding single mutants and (B) wt and TSHR double mutants containing S281N and corresponding single mutants. cAMP accumulation assays were performed with transiently transfected COS-7 cells. Forty-eight hours after transfection, COS-7 cells were incubated in the absence (solid bars) or presence (open bars) of $100 \mathrm{mU} / \mathrm{ml}$ bTSH. cAMP levels were determined as described in Materials and methods. Data are expressed as relative to wt basal and given as means \pm S.E.M. of two independent experiments, each carried out in triplicate. 
A

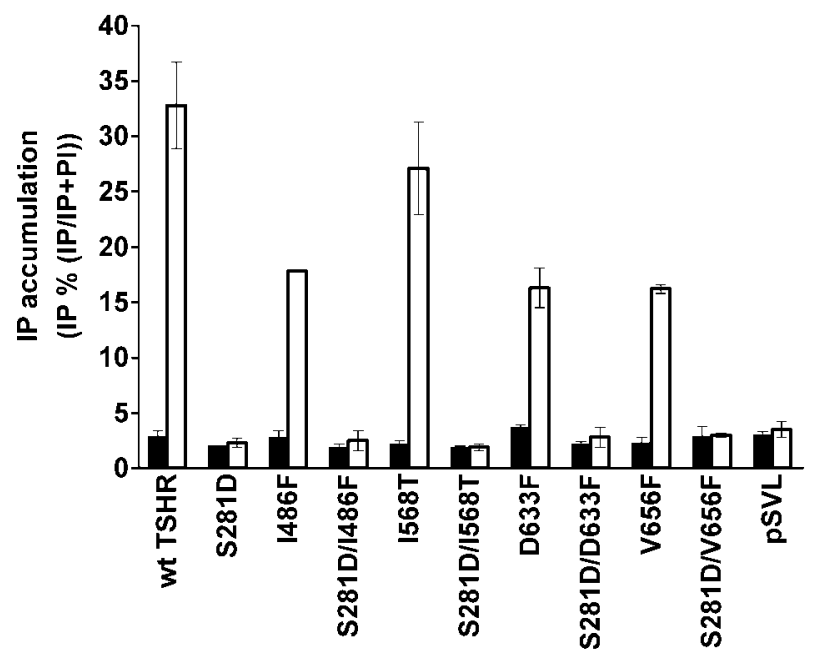

B

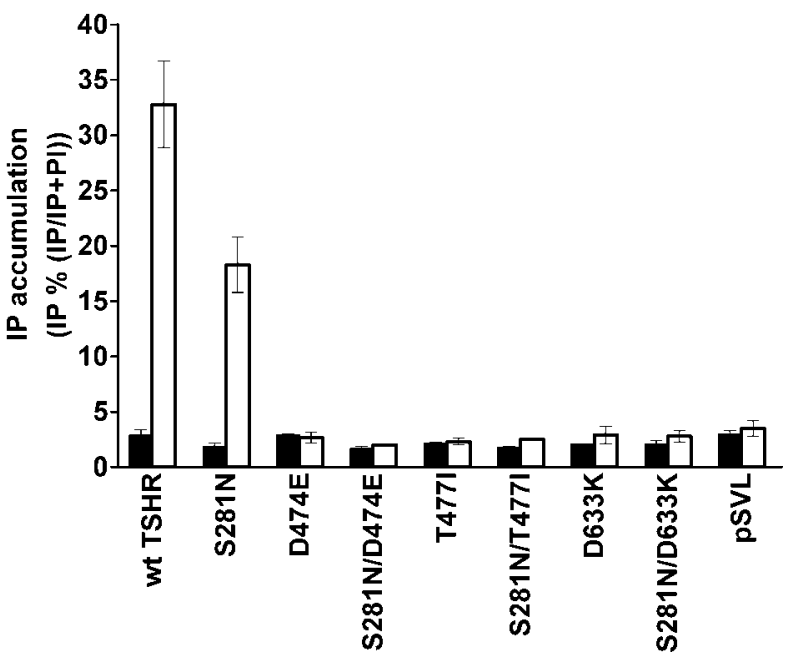

Figure 4 Basal and TSH-stimulated IP accumulation. (A) wt and TSHR double mutants with S281D and corresponding single mutants and (B) wt and TSHR double mutants containing S281N and corresponding single mutants. Forty-eight hours after transfection, cells were labeled with $2 \mu \mathrm{Ci} / \mathrm{ml}^{\text {[myo- }}{ }^{3} \mathrm{H}$ ] inositol for $8 \mathrm{~h}$ and subsequently incubated in the absence (solid bars) or presence (open bars) of $100 \mathrm{mU} / \mathrm{ml} \mathrm{bTSH}$. IP accumulation was determined as described in Materials and methods. Data are expressed as percent radioactivity incorporated in IPs over the sum of radioactivity in IPs and PI, and presented as means \pm S.E.M. of two independent experiments, each carried out in triplicate.

structure (10). However, the common conclusion of all models is that interactions between the hormone binding ECD and the ECLs or the TMDs during receptor activation are very likely.

S281 is the only position in the ECD which is affected by constitutively activating in vivo mutations and several studies have identified S281 as an important key position for intramolecular signal transduction (23-26). We therefore decided to use these features of S281 to investigate the hypothesis of potential selfinhibitory interactions between the ECD and the ECLs as well as the 6th TMD by characterization of double mutants in these receptor domains.

Besides the reported importance of the extracellular loops for hormone binding $(40,41)$, these receptor domains are likely to be involved in signal transduction. This is indicated by inactivating mutations in the 1st ECL and constitutively activating mutations which were identified in all three ECLs (42). Inactivating mutations in the 1st ECL and the 6th TMD were dominant in all double mutants with the constitutively activating S281N. The double mutants S281N/D474E and S281N/T477I showed virtually no cell surface expression and receptor activity. Since the mutant receptors were detectable within permeabilized cells amino acid substitutions at these positions in the 1st ECL obviously cause strong conformational changes of the TSHR and, therefore, interfere with correct folding and transport of the receptor molecules to the cell surface (Fig. 2). Moreover, this underlines that these amino acids in the 1st ECL have a strong effect on TSHR signaling, which has also been shown in other studies. The introduction of the mutations D419A, K, E, N and R into the 1st ECL of the CG/LHR (TSHR: D474)
(43) and D422A and K426A (TSHR: D474 and H478) into the 1st ECL of the FSHR (44) also affected signaling of the receptors. In summary, the dominance of the inactivating mutations in the 1st ECL of the TSHR indicates that a constitutively activating mutation in the ECD cannot bypass inactivating mutations within the 1st ECL.

In previous studies, we (36) and others (45) have shown that D633 in the 6th TMD is involved in the H-bond network between the 6th TMD and the 7th TMD and therefore is important for TSHR activation. The substitution of D633 with a positively charged arginine locked the TSHR in a completely inactive state (36). The introduction of the D633K mutation also strongly reduced TSHR activity (Table 1), most likely also by disturbing the intramolecular H-bond network and lowering the mobility of the 6th and 7th TMD. In addition, an influence of the 6th TMD on TSHR dimerization is discussed $(46,47)$, which might be another explanation for the impaired G-protein activation caused by D633K. In our published TSHR model, however, D633 points into a space between the helices of the 6th, 7th and 3rd TMD, right in the center of the sevenhelix bundle (36). Therefore mutations at this position could most likely only indirectly affect TSHR dimerization, e.g. via induced conformational changes. Our finding that S281N/D633K remains inactive like D633K confirms the pivotal role of helices 6 and 7 for receptor activation and supports our conclusion that disruption of the intramolecular signal transduction in the serpentine domain cannot be compensated or bypassed by the introduction of activating mutations into the ECD.

In the 1st and 2nd ECL, one Ile residue seems to be important for constitutive activity $(16,48,49)$ (TSH 
Receptor mutation Database II, http://www.uni-leipzig. de/ innere/) (21). Three different constitutively activating mutations have been described in the 3rd ECL (32, 34, 48-50) (TSH Receptor mutation Database II, http://www.uni-leipzig.de/ innere/). The higher incidence of constitutively activating mutations within the 3rd ECL compared with the 1st and 2nd ECLs could be due to its vicinity to the 6 th and 7 th transmembrane segments and the resulting influence on the conformation of these receptor domains, which have been identified as one of the major determinants for the maintenance of the inactive receptor conformation $(36,45,51)$.

Substitution of the wt S281 by most amino acid residues causes the destabilization of the inactive receptor conformation and, therefore, induces constitutive activation of TSHR signaling. In addition, introduction of aspartate at this position seems to interfere with full responsiveness to TSH. The mutation S281D was chosen for our investigations because it is characterized by constitutive cAMP accumulation, but clearly reduced increase in TSH-stimulated cAMP production, which is most likely due to a disturbed ECD conformation as proposed by the low cell surface expression of S281D.

All double mutants with S281D showed a phenotype comparable with the S281D single mutant. Introduction of S281D caused a reduction of basal and TSHstimulated cAMP accumulation to the level of S281D and the loss of IP production of all constitutively activating in vivo mutants in the three ECLs. The dominance of the S281D mutation in the ECD in all double mutants suggested that an intact ECD conformation is necessary for proper intramolecular signaling transmitted by the ECLs and the TMD. Recent studies have shown that the deletion of the ECD of the TSHR led to the loss of constitutive receptor activation of the mutants $\mathrm{I} 486 \mathrm{~F}$ and I568T in the 1st and 2nd ECL respectively, while the mutant D633A in the 6th TMD was able to fully activate the truncated receptor also (16). In our study, the double mutant S281D/D633F showed reduced receptor activity which might be related to receptor misfolding caused by S281D. Taken together, our data demonstrated that the decrease of TSH-stimulated cAMP production caused by a mutant in the ECD cannot be restored by constitutively activating mutations in the ECLs and the 6th TMD, which are located downstream in the intramolecular receptor signaling cascade. This confirms - except for the 6th TMD - the conclusion made by Vlaeminck-Guillem et al. (16) that the ectodomain is proposed to have a positive effect on the activity of the serpentine domain as full TSHR activation and intramolecular signal transduction obviously require the undisturbed interplay between the ECD and the serpentine domain. Our findings concerning the impact of a mutant in the ECD on the TMD are supported by the work of Gaudin et al. (52), who showed that introduction of an inactivating mutation into the ECD of the vasoactive intestinal peptide (VIP)-1 receptor abolished the effect of a constitutively active mutation in the transmembrane domain. Gaudin et al. (52) assumed that constitutive activity of the VIP-1 receptor requires the functional integrity of the N-terminal extracellular VIP-binding domain.

Taken together, the results in our study provide evidence for the importance of intramolecular interactions between the ECD and the ECLs as well as the 6th TMD and the interdependence of these receptor domains in the process of TSHR activation and intramolecular signal transduction.

\section{Acknowledgements}

We should like to thank Mrs Eileen Bösenberg for her excellent technical assistance. We thank BRAHMS Diagnostica (Berlin, Germany) for providing $\left[{ }^{125} \mathrm{I}\right] \mathrm{bTSH}$. This work was supported by the Deutsche Forschungsgemeinschaft (Pa 423/3-2) and the Bundesministerium für Bildung und Forschung $(\mathrm{BMB}+\mathrm{F})$, Interdisciplinary Center for Clinical Research (IZKF) at the University of Leipzig (Project B 19).

\section{References}

1 Gudermann T, Nurnberg B \& Schultz G. Receptors and G proteins as primary components of transmembrane signal transduction. Part 1. G-protein-coupled receptors: structure and function. Journal of Molecular Medicine 199573 51-63.

2 Nagayama Y \& Rapoport B. The thyrotropin receptor 25 years after its discovery: new insight after its molecular cloning. Molecular Endocrinology 19926 145-156.

3 Segaloff DL \& Ascoli M. The lutropin/choriogonadotropin receptor .. 4 years later. Endocrine Reviews 199314 324-347.

4 Simoni M, Gromoll J \& Nieschlag E. The follicle-stimulating hormone receptor: biochemistry, molecular biology, physiology, and pathophysiology. Endocrine Reviews 199718 739-773.

5 Rapoport B, Chazenbalk GD, Jaume JC \& McLachlan SM. The thyrotropin (TSH) receptor: interaction with TSH and autoantibodies. Endocrine Reviews 199819 673-716.

6 Vassart G, Desarnaud F, Duprez L, Eggerickx D, Labbe O, Libert F, Mollereau C, Parma J, Paschke R, Tonacchera M, Vanderhaeghen P, Van Sande J, Dumont J \& Parmentier M. The $G$ protein-coupled receptor family and one of its members, the TSH receptor. Annals of the New York Academy of Sciences 1995 $76623-30$.

7 Thomas D, Rozell TG, Liu X \& Segaloff DL. Mutational analyses of the extracellular domain of the full-length lutropin/choriogonadotropin receptor suggest leucine-rich repeats 1-6 are involved in hormone binding. Molecular Endocrinology 199610 760-768.

8 Braun T, Schofield PR \& Sprengel R. Amino-terminal leucine-rich repeats in gonadotropin receptors determine hormone selectivity. EMBO Journal $1991101885-1890$.

9 Smits G, Govaerts C, Nubourgh I, Pardo L, Vassart G \& Costagliola S. Lysine 183 and glutamic acid 157 of the TSH receptor: two interacting residues with a key role in determining specificity toward TSH and human CG. Molecular Endocrinology 2002 $16722-735$.

10 Sangkuhl K, Schulz A, Schultz G \& Schoneberg T. Structural requirements for mutational lutropin/choriogonadotropin receptor activation. Journal of Biological Chemistry $2002 \mathbf{2 7 7}$ $47748-47755$. 
11 Bhowmick N, Narayan P \& Puett D. Identification of ionizable amino acid residues on the extracellular domain of the lutropin receptor involved in ligand binding. Endocrinology 1999140 4558-4563.

12 Vischer HF, Granneman JC, Noordam MJ, Mosselman S \& Bogerd J. Ligand selectivity of gonadotropin receptors. Role of the betastrands of extracellular leucine-rich repeats 3 and 6 of the human luteinizing hormone receptor. Journal of Biological Chemistry 2003278 15505-15513.

13 Song YS, Ji I, Beauchamp J, Isaacs NW \& Ji TH. Hormone interactions to Leu-rich repeats in the gonadotropin receptors. II. Analysis of Leu-rich repeat 4 of human luteinizing hormone/ chorionic gonadotropin receptor. Journal of Biological Chemistry $20012763436-3442$.

14 Seetharamaiah GS, Kurosky A, Desai RK, Dallas JS \& Prabhakar BS. A recombinant extracellular domain of the thyrotropin (TSH) receptor binds TSH in the absence of membranes. Endocrinology $1994134549-554$.

15 Shi Y, Zou M, Parhar RS \& Farid NR. High-affinity binding of thyrotropin to the extracellular domain of its receptor transfected in Chinese hamster ovary cells. Thyroid 19933 129-133.

16 Vlaeminck-Guillem V, Ho SC, Rodien P, Vassart G \& Costagliola S. Activation of the cAMP pathway by the TSH receptor involves switching of the ectodomain from a tethered inverse agonist to an agonist. Molecular Endocrinology 200216 736-746.

17 Zhang M, Tong KP, Fremont V, Chen J, Narayan P, Puett D, Weintraub BD \& Szkudlinski MW. The extracellular domain suppresses constitutive activity of the transmembrane domain of the human TSH receptor: implications for hormone-receptor interaction and antagonist design. Endocrinology $2000 \mathbf{1 4 1}$ 3514-3517.

18 Cetani F, Tonacchera M \& Vassart G. Differential effects of $\mathrm{NaCl}$ concentration on the constitutive activity of the thyrotropin and the luteinizing hormone/chorionic gonadotropin receptors. FEBS Letters 1996378 27-31.

19 Van Sande J, Massart C, Costagliola S, Allgeier A, Cetani F, Vassart G \& Dumont JE. Specific activation of the thyrotropin receptor by trypsin. Molecular and Cellular Endocrinology 1996 $119161-168$

20 Zhang ML, Sugawa H, Kosugi S \& Mori T. Constitutive activation of the thyrotropin receptor by deletion of a portion of the extracellular domain. Biochemical and Biophysical Research Communications $1995211205-210$.

21 Fuhrer D, Lachmund P, Nebel IT \& Paschke R. The thyrotropin receptor mutation database: update 2003. Thyroid 200313 1123-1126.

22 Paschke $\mathrm{R}$ \& Ludgate $\mathrm{M}$. The thyrotropin receptor in thyroid diseases. New England Journal of Medicine 1997337 1675-1681.

23 Duprez L, Parma J, Costagliola S, Hermans J, Van Sande J, Dumont JE \& Vassart G. Constitutive activation of the TSH receptor by spontaneous mutations affecting the N-terminal extracellular domain. FEBS Letters $1997 \mathbf{4 0 9} 469-474$.

24 Ho SC, Van Sande J, Lefort A, Vassart G \& Costagliola S. Effects of mutations involving the highly conserved S281HCC motif in the extracellular domain of the thyrotropin (TSH) receptor on TSH binding and constitutive activity. Endocrinology $2001 \mathbf{1 4 2}$ $2760-2767$.

25 Kopp P, Muirhead S, Jourdain N, Gu WX, Jameson JL \& Rodd C. Congenital hyperthyroidism caused by a solitary toxic adenoma harboring a novel somatic mutation (serine $281 \rightarrow$ isoleucine) in the extracellular domain of the thyrotropin receptor. Journal of Clinical Investigation $1997 \mathbf{1 0 0} 1634-1639$.

26 Parma J, Duprez L, Van Sande J, Hermans J, Rocmans P, Van Vliet G, Costagliola S, Rodien P, Dumont JE \& Vassart G. Diversity and prevalence of somatic mutations in the thyrotropin receptor and Gs alpha genes as a cause of toxic thyroid adenomas. Journal of Clinical Endocrinology and Metabolism 199782 2695-2701.

27 Nakabayashi K, Kudo M, Kobilka B \& Hsueh AJ. Activation of the luteinizing hormone receptor following substitution of Ser-277 with selective hydrophobic residues in the ectodomain hinge region. Journal of Biological Chemistry $200027530264-30271$.

28 Higuchi R. Using PCR to engineer DNA. In PCR Technology, pp 61-70, pp . Ed. HA Erlich. New York: Stockton Press, 1989.

29 Libert F, Lefort A, Gerard C, Parmentier M, Perret J, Ludgate M, Dumont JE \& Vassart G. Cloning, sequencing and expression of the human thyrotropin (TSH) receptor: evidence for binding of autoantibodies. Biochemical and Biophysical Research Communications 1989165 1250-1255.

30 Wonerow P, Schoneberg T, Schultz G, Gudermann T \& Paschke R. Deletions in the third intracellular loop of the thyrotropin receptor. A new mechanism for constitutive activation. Journal of Biological Chemistry 1998273 7900-7905.

31 Berridge MJ. Rapid accumulation of inositol trisphosphate reveals that agonists hydrolyse polyphosphoinositides instead of phosphatidylinositol. Biochemical Journal 1983212 849-858.

32 Wonerow P, Chey S, Fuhrer D, Holzapfel HP \& Paschke R. Functional characterization of five constitutively activating thyrotrophin receptor mutations. Clinical Endocrinology $2000 \mathbf{5 3}$ 461-468.

33 Swillens S. Interpretation of binding curves obtained with high receptor concentrations: practical aid for computer analysis. Molecular Pharmacology 199547 1197-1203.

34 Fuhrer D, Holzapfel HP, Wonerow P, Scherbaum WA \& Paschke R. Somatic mutations in the thyrotropin receptor gene and not in the Gs alpha protein gene in 31 toxic thyroid nodules. Journal of Clinical Endocrinology and Metabolism 199782 3885-3891.

35 Kosugi S, Matsuda A, Hai N, Aoki N, Sugawa H \& Mori T. Aspartate- 474 in the first exoplasmic loop of the thyrotropin receptor is crucial for receptor activation. FEBS Letters $1997 \mathbf{4 0 6} 139-141$.

36 Neumann S, Krause G, Chey S \& Paschke R. A free carboxylate oxygen in the side chain of position 674 in transmembrane domain 7 is necessary for TSH receptor activation. Molecular Endocrinology 200115 1294-1305.

37 Parma J, Van Sande J, Swillens S, Tonacchera M, Dumont J \& Vassart G. Somatic mutations causing constitutive activity of the thyrotropin receptor are the major cause of hyperfunctioning thyroid adenomas: identification of additional mutations activating both the cyclic adenosine $3^{\prime}, 5^{\prime}$-monophosphate and inositol phosphate-Ca2 + cascades. Molecular Endocrinology 19959 725-733.

38 Tonacchera M, Agretti P, Pinchera A, Rosellini V, Perri A, Collecchi P, Vitti P \& Chiovato L. Congenital hypothyroidism with impaired thyroid response to thyrotropin (TSH) and absent circulating thyroglobulin: evidence for a new inactivating mutation of the TSH receptor gene. Journal of Clinical Endocrinology and Metabolism 200085 1001-1008.

39 Van Sande J, Parma J, Tonacchera M, Swillens S, Dumont J \& Vassart G. Somatic and germline mutations of the TSH receptor gene in thyroid diseases. Journal of Clinical Endocrinology and Metabolism $1995 \mathbf{8 0} 2577-2585$.

40 Haraguchi K, Saito T, Endo T \& Onaya T. Disruption of the first extracellular loop of thyrotropin receptor prevents ligand binding. Life Sciences $199455961-968$.

41 Kaneshige M, Haraguchi K, Endo T, Anzai E \& Onaya T. The functional significance of the second extracellular loop of thyrotropin receptor in thyrotropin- and thyroid stimulating antibody-dependent signal transduction. Hormone and Metabolic Research 1995 27 267-271.

42 Wonerow P, Neumann S, Gudermann T \& Paschke R. Thyrotropin receptor mutations as a tool to understand thyrotropin receptor action. Journal of Molecular Medicine 2001 79 707-721.

43 Ji I \& Ji TH. Receptor activation is distinct from hormone binding in intact lutropin-choriogonadotropin receptors and Asp397 is important for receptor activation. Journal of Biological Chemistry $199326820851-20854$.

44 Ji I \& Ji TH. Differential roles of exoloop 1 of the human follicle-stimulating hormone receptor in hormone binding and receptor activation. Journal of Biological Chemistry $1995 \mathbf{2 7 0}$ $15970-15973$. 
45 Govaerts C, Lefort A, Costagliola S, Wodak SJ, Ballesteros JA, Van Sande J, Pardo L \& Vassart G. A conserved Asn in transmembrane helix 7 is an on/off switch in the activation of the thyrotropin receptor. Journal of Biological Chemistry $20012 \mathbf{2 7 6}$ 22991-22999.

46 Farid NR \& Szkudlinski MW. Minireview: structural and functional evolution of the thyrotropin receptor. Endocrinology 2004 $1454048-4057$.

47 Kaczur V, Puskas LG, Takacs M, Racz IA, Szendroi A, Toth S, Nagy Z, Szalai C, Balazs C, Falus A, Knudsen B \& Farid NR. Evolution of the thyrotropin receptor: a $\mathrm{G}$ protein coupled receptor with an intrinsic capacity to dimerize. Molecular Genetics and Metabolism 200378 275-290.

48 Trultzsch B, Nebel T \& Paschke R. The TSH receptor mutation database. European Journal of Endocrinology 1999140 VII.

49 Trulzsch B, Nebel T \& Paschke R. The thyrotropin receptor mutation database. Thyroid 19999 521-522.

50 Tonacchera M, Van Sande J, Cetani F, Swillens S, Schvartz C, Winiszewski P, Portmann L, Dumont JE, Vassart G \& Parma J.
Functional characteristics of three new germline mutations of the thyrotropin receptor gene causing autosomal dominant toxic thyroid hyperplasia. Journal of Clinical Endocrinology and Metabolism $199681547-554$.

51 Shi Y, Zou M, Ahring P, Al-Sedairy ST \& Farid NR. Thyrotropin internalization is directed by a highly conserved motif in the seventh transmembrane region of its receptor. Endocrine 19953 409-414.

52 Gaudin P, Maoret JJ, Couvineau A, Rouyer-Fessard C \& Laburthe M. Constitutive activation of the human vasoactive intestinal peptide 1 receptor, a member of the new class II family of $\mathrm{G}$ protein-coupled receptors. Journal of Biological Chemistry 1998273 4990-4996.

Received 13 October 2004

Accepted 17 January 2005 